\title{
The Ganges Basin management and community empowerment
}

\author{
Mohhamed Anwar Hossen
}

\section{Correspondence:}

anwar_sociology@yahoo.com Department of Sociology, Dhaka

University, Dhaka, Bangladesh

\section{Springer}

\begin{abstract}
This paper explores the ecological effects of the top-down Ganges Basin water management systems in Chapra, Bangladesh, based on my ethnographic fieldwork ${ }^{a}$ data collected in 2011-12. An example of this top-down system is the Farakka Barrage in India that causes major ecological system failures and challenges to community livelihoods. The reduction in Ganges Basin water flow in Bangladesh based on the pre and post Farakka comparison is helpful in understanding these failures and their effects on community livelihoods. My argument is that basin communities are capable of becoming empowered by Ganges Basin water management and failures in the management create major challenges to the livelihood of these communities. In this context, I analyze the current Ganges Basin management practices, focusing specifically on the Joint River Commission and the 1996 Ganges Treaty between India and Bangladesh, and their effects on the basin communities in Chapra. My fieldwork data point out that the current shortcomings in basin management can be overcome with an improved management system. Water governance based on a multilateral approach is a way to restore the basin's ecological systems and promote community empowerment. Based on this empowerment argument, this paper is divided into the following major sections: importance of the basin ecosystems for protecting community livelihoods, limitations of current basin management practices and community survival challenges, and proposed water governance for community empowerment.
\end{abstract}

\section{Introduction}

The Ganges Basin originates from the Himalaya Mountains, passing through China, Nepal, India, and Bangladesh, and ending in the Bay of Bengal. The water develops a single ecological system throughout the basin, which develops ecological embeddedness (Whiteman and Cooper 2000) and watershed (Orlove and Caton 2010). Historically, this ecosystem generates local biotic and abiotic components based on the seasonal flow of borsha (wet) and khora (dry). In Bangladesh, this ecosystem has major flora and fauna characteristics which provide abundant ecological resources like local crops, cropland siltation and wild fish. These resources are foundations for empowerment in Chapra; here I describe empowerment as community historical rights to access local ecological resources for protecting their traditional self-sufficiency and promoting their social mobility. The recognition of empowerment approach in the Ganges Basin management policy can restore community empowerment as they are historical rights based on common property (Mosse 2003:5).

(c) 2014 Anwar Hossen; licensee Springer. This is an Open Access article distributed under the terms of the Creative Commons Attribution License (http://creativecommons.org/licenses/by/4.0), which permits unrestricted use, distribution, and reproduction in any medium, provided the original work is properly credited. 
However, the current bilateral and top-down basin management practices are major reasons for ecosystem failures and challenges to community survival in Chapra. These practices had begun during the British Colonial period in the Indian Sub-continent. The British colonizers established a water management discourse that described the colonized margins as backward and traditional people who need to empower with water and agricultural modernization (D'Souza 2006:621). In 1854, for example, the British Government in India established 2,298 miles of canals and distributaries on the upper Ganges Basin (Khan 1996). D’Souza (2006:621) refers these water development projects as "colonial hydrology," and after independent, India built about 4300 dams by 1994 and is considered one of the major dam building countries of the world (Hill 2006:149). The Farakka Barrage is an example of India's water management on the Ganges Basin. This barrage creates a major water management conflict between India and Pakistan (1947-1971), and currently between India and Bangladesh. Based on bilateral hydropolitics, the Governments of India signed two treaties in 1977 and 1996 and two memoranda of understanding in 1983 and 1985 with the Governments of Bangladesh (Khan 1996). These management practices fail to improve the basin flow and fail to empower local communities. Currently, the government of India is executing National River Linking Project (NRLP) that plans to divert water flow in India from the Brahmaputra to the Ganges Basin. The implementation of this NRLP is likely to cause ecological disasters and local community economic vulnerabilities for the rest of Bangladesh like the Farakka Barrage effects on Ganges Dependent Area in Bangladesh.

These practices, based on Lebel et al. (2005) and Escobar's (1996) arguments, can be described as nature as social construct based on a specific power structure which depicts political ecology of natural resource management. This political construction of nature had begun during the colonial period in the Indian subcontinent (D'Souza 2006) which continued with reductionist approaches (Bandyopadhyay and Ghosh 2009). After this period, the central government in India promotes hydrological nationalism (Bandyopadhyay 2006), on which a bilateral practice is based (Crow and Singh 2000). For example, the Indian government established the Joint River Commission (JRC) in 1972 with Bangladesh to manage the Ganges Basin by excluding the other basin countries of China and Nepal. This bilateral management practice has caused ecosystem fragmentation and isolation which is one water policy limitations and community survival challenges. This practice places a political nature to water management, ascribing water with social, economic, and bio-political elements (Hastrup 2013). The economic interests dominate hydropolitics, promoting water as a commodity (Polanyi 1944). Thus, politico-economic aspects of water resource management create negative ecological outcomes (Peterson 2000). The Farakka Barrage is an example of this which had established in 1975 and has had spatial and temporal effects in the Ganges Dependent Area in Bangladesh (Bharati and Jayakody 2011; Sarker 2004; Swain 1996). This paper focuses on the effects of this barrage which creates major ecosystem failures and survival challenges in Chapra. To overcome these challenges, it is important to develop a better water policy for community empowerment.

My fieldwork data suggests that water resource governance can overcome these challenges and can promote community empowerment. Water governance means to incorporate community voices into water policy and to ensure local community participation in the basin management. For this purpose, multilateral rather than the current bilateral domination is a prerequisite for creating a scope for this governance approach. This 
bottom-up practice is essential to ensure ecosystem sustainability and community empowerment in the Ganges Basin (Agrawal 2003; Agrawal and Gibson 2001; Bulkeley 2005; Castro 2007; Dove 1986; Folke et al. 2005; Hukka et al. 2010; Mirumachi and Allan 2007; Ostrom et al. 1999). The government of India and other countries in the Ganges Basin need to recognize this governance approach for community empowerment, for overcoming current water management limitations, and for protecting traditional empowerment systems in Chapra, Bangladesh.

\section{Basin ecosystems and current management reviews}

\section{Basin ecosystem and Chapra}

The Ganges Basin ecological systems originate from the headwater of the Himalaya Mountains, which integrate landscapes and communities irrespective of political boundaries in China, Nepal, India and Bangladesh (Figure 1). The basin catchment areas are situated three percent in China, fourteen percent in Nepal, seventy nine percent in India, and four percent in Bangladesh (Ahmad and Ahmed 2004). The two major branches of the Ganges are the Alakananda and Bhagirthi, which flow downstream in a southwardly direction and meet in Garhwal District of India's Uttarkhand state. One major tributary, Rama Ganga, originates from the Himalaya range in Nepal and meets the Ganges before merging with Yamuna (Allahabad), the Gomati, and the Ghagra in India. Three Nepalese tributaries of the Sarda, the Karnali-Rapti, and the Gandak-Kosi merge with these branches of the Ganges in India. The Gandak-Kosi connects with their tributaries, the Buri

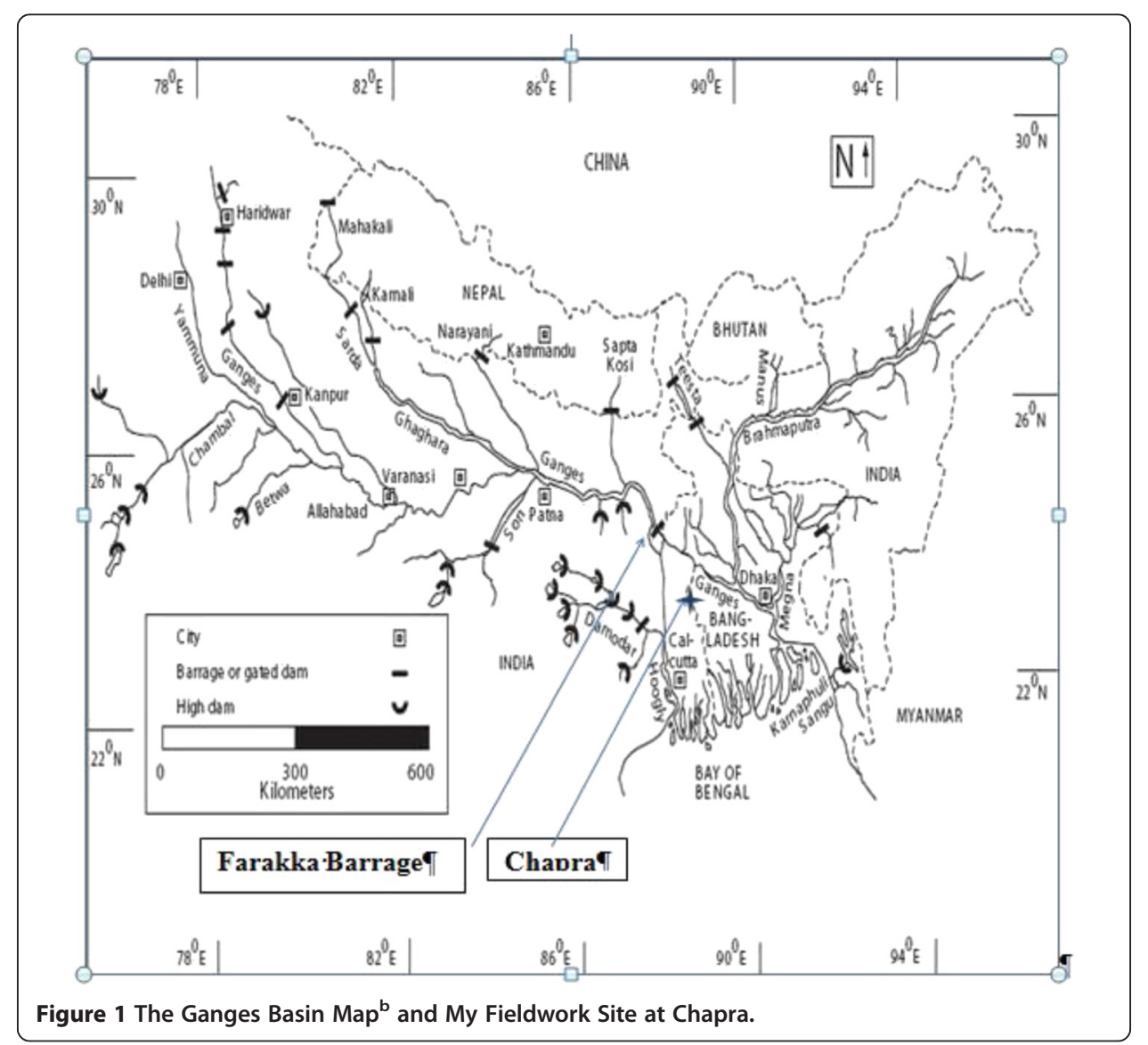


Gandak-Bagmati, the Kamala, and the Sun-Arun Kosi (Parua 2010). The Karnali, the Gandak, and the Kosi originate in China (Tibet), flow through Nepal, meet the Ganges in India, and merge with the Padma River in Bangladesh. These basin flows develop biotic and non-biotic components that flourish, coordinate, and diversify ecological systems which support local croplands, forests, wetlands, vegetation, lakes, and communities.

This ecological integrity originates from the combined water flows of the Ganges Basin, which come from China, Nepal, India, and Bangladesh. Historically, this integrity provides the foundation for local ecological resources and community livelihoods at Chapra and this foundation can be described as waterscapes (Baviskar 2007) and as socioecological systems (Wagner 2013). The borsha season covers four months from June to September, and provides ecological services for the whole year. Local people produce staple foods, rice paddy like aman, based on these ecological services, which is a major component of community food security. Croplands receive siltation from the borsha flow that satisfy cropland fertility and also washes away cropland wastage. The regular khora season covers the four months from January to April and provides different ecological services for local agricultural and employment practices. This dry season allows fisheries to be accessible from local water bodies. Moreover, this season brings different fruits and crops to the Chapra community. I found these ecosystem-community linkages based on my fieldwork at Chapra. Chapra is a rural agricultural community at Kushtia in Bangladesh. In Chapra, seventy six percent of people are involved in agricultural production (BEC 2011). This Chapra village is situated on the Gorai River bank. This river originates from the Ganges River in Kushtia and moves downstream to the Bay of Bengal through the Madhumati and Baleswar Rivers. This river flows for 199 kilometers and has a catchment area of 15,160 square kilometers, and is a major freshwater ecological system of the southwestern hydrological zone in Bangladesh (Islam and Gnauck 2011). The freshwater ecosystem is vital for human life and social well-being (Baron et al. 2002). These ecological systemlivelihood linkages are called total social facts (Orlove and Caton 2010).

I used focus group discussions and in-depth case studies for data collection at Chapra. There were 44 focus group discussants and 4 in-depth case respondents for my primary data collection. Additionally, I collected historical data flow on the Ganges Basin at the Hardinge Bridge Station in 1960-2010 from the central government in Bangladesh. This secondary data in addition to primary data are the foundations for exploring the effects of current basin management practices on community livelihoods at Chapra.

\section{Current management practices and community challenges}

The current basin management is fragmented because of India's bilateral domination (Hossen 2012; Mirza 2004; Nilsson et al. 2005). The Nehru Government began technology dominated hydrological nationalism for industrial development (Bandyopadhyay 2006). This nationalism is connected to India's foreign policy, which focuses on a bilateral preference in managing the Ganges Basin (Crow and Singh 2000). An example of this preference is the Joint River Commission (JRC) that was established between India and Bangladesh although the basin shares with other countries of China and Nepal. This bilateral and top-down domination is so strong that it is similar to the previous British colonial 'divide and rule' administrative practices in the Indian Subcontinent. The British 
Regime (1757-1947) divided Muslims from Hindus in their colonial power structures (Hartmann and Boyce 1983). Similarly, the Indian bilateral domination creates divide and rules between Nepal, Bhutan, and Bangladesh. In addition to this domination, the British Colonial Regime in India developed the top-down water management systems, which can be considered a colonial legacy (Bandyopathyay and Shiva 1988), colonial hydrology (D'Souza 2006), and a reductionist approach (Bandyopadhyay and Ghosh 2009).

Currently, this reductionist perspective follows the World Bank's "economics first" strategy, which views water as a commodity for economic development and fails to recognize the Ganges Basin ecological systems and community historical rights. This economic aspect is at the center of promoting bilateral basin management in India to control the Ganges Basin. The Indian government does not allow the involvement of a third country like China or Nepal as this preference is helpful for India to ensure divide and rules (McGregor 2000). This exclusionary practice is dominated by multilevel interests based on spatial, temporal and jurisdictional complexity (Lebel et al. 2005). Two examples of this bilateral preference are the 1996 Ganges (India and Bangladesh) and Mahakhali (India and Nepal) Treaties. These bilateral practices created "ample water, ample poverty" (Bandyopadhyay and Ghosh 2009:51) because of the river ecological resource failures. The Joint River Commission fails to address the ecological issues in Bangladesh because of complex hydropolitics over the Ganges Basin management.

\section{Joint river commission for the Ganges basin management}

The Joint River Commission (JRC) is a major bilateral and top-down water management institution in the Ganges Basin. The Indian government established the JRC with Bangladesh in 1972 (Hossain 1981). The JRC fails to include the other basin countries of China and Nepal, which majorly limits basin ecological embeddedness (Arango et al. 2010) and watershed (Orlove and Caton 2010). In addition to this bilateral confinement, this watershed embeddedness is dominated by technocentric basin water management which excludes community voices about ecological resources. According to the statutes, the JRC has two engineers among the three members and one chairman (MoWR n.d.). Article four points out that the major objectives of the JRC are to develop joint flood control mechanisms and to maintain liaisons between the two countries. These guidelines fail to incorporate a minimum understanding of ecological systems and community historical rights.

Furthermore, the JRC statutes place major limitations on institutional structure and jurisdiction (Nishat and Faisal 2000). The JRC does not have the freedom to implement its research findings. They can only recommend findings to their respective governments in India and Bangladesh, and neither government is officially supposed to implement the recommendations. Most of the time, the JRC works on politically motivated water issues and there are no institutional systems to work as an independent entity. This political domination satisfies corporate elites and excludes community interests.

Political dominance of the JRC activities causes major challenges for its independent existence (Faisal 2002). One example is the Ganges Basin water flow crises during the dry season (Khan 1996). The Prime Ministers of India and Bangladesh met in 1974 and agreed to develop a water management strategy to address the drought problem. Based on this meeting, the governments directed the JRC to find a solution of this problem. The 
JRC study agreed that the Ganges did not have enough water to meet both countries' water demands during the dry season. They recommended water augmentation as a viable option. However, the JRC failed to reach a unanimous decision on this augmentation. The JRC members in Bangladesh proposed building water reservoirs in Nepal while the Indian members proposed transferring water from the Brahmaputra to the Ganges Basin. The Indian JRC members argued that the Bangladesh members' recommendations were beyond JRC's jurisdiction (Khan 1996). This jurisdictional issue is a political one based on bilateral hydropolitics.

This political domination creates the JRC an ineffective institution. Without recognizing the JRC role, both governments, for example, organized six meetings from 1990-92 on water disputes of the Monu, Muhuri, Khowai, Gumti, Dharla and Dudhkuamr Rivers. This exclusion of the JRC can be attributed to JRC's dysfunctional nature because the JRC fails to organize a minimum number of meetings every year, according to its statutes. Again, the 1996 Ganges Treaty established another committee, the Joint Committee (JC), which reduced the JRC's role in basin management. Because of these political decisions, the JRC has failed to make any major achievements since its inception in 1972 (Gupta et al. 2005). I elaborate these JRC limitations in the context of the Farakka Barrage dispute resolution.

\section{JRC and the farakka dispute resolution}

One major challenge of the JRC is to resolve the Farakka Barrage dispute between India and Bangladesh. The government in India established the Farakka Barrage unilaterally on the Ganges Basin on 21 April 1975 about eleven miles upstream from the Bangladesh border. The purpose of this barrage was to ensure navigation of the Kolkata Port and water supplies of Kolkata city (Rahaman 2009). The then Pakistan Government objected to the Farakka construction plan on 29 October 1951 based on ecological concerns and organized five rounds of meetings with India in 1960-1970 (Khalid 2010). The Indian government did not disclose this barrage information to the Pakistan Government and said it was only at the planning stage. After the independence of Bangladesh from Pakistan in 1971, the government in Bangladesh began ministerial level meetings with India in 1973-74. In 1974, the then president of Bangladesh Government, Sheikh Mujibur Rahman, raised concerns about the Farakka diversion (Hossain 1998). In the meantime, the barrage was ready for operation and the government in Bangladesh was disappointed by this unilateral action. Because of Indian hydropolitical domination, the Bangladesh Government agreed to operate the Farakka Barrage for a forty day trial period in 1975 (Swain 1996). After this trial period, India continued to divert water unilaterally (Nakayama 1997). The JRC failed to perform an appropriate role in preventing this unilateral dominance over the Ganges Basin.

Due to India's bilateral hydropolitics, the then president of the World Bank, Robert McNamara, as the mediator, failed to resolve the Ganges dispute in 1976. The World Bank proposed constructing water reservoirs in Nepal to provide water during the dry season to Nepal, India, and Bangladesh. Another goal was to reduce the negative ecological consequences of the Farakka diversion and to generate hydroelectric power (Nakayama 1997). However, India did not agree to this proposal due to bilateral hydropolitics (Biswas 1999). 
Historically, the Indian government has signed different bilateral treaties with Bangladesh (1977, 1983 and 1996) and Nepal (1927, 1966 and 1996) which have failed to recognize ecosystems in the Ganges Basin. The most recent treaty, the 1996 Ganges Treaty, was signed on 12 December 1996 for the thirty-year period (GoB 1996). The goal of this treaty is to secure water sharing of the Ganges River specifically during the dry season.

Based on the 1996 treaty, India and Bangladesh will receive more than 30,000 cusecs water every other ten day period during the summer season (Table 1). Article-II (iii) informs us that if the basin flow is below 50,000 cusecs in any ten-day period at the Farakka point, the Indian and Bangladesh governments will contact each other and ensure "equity, fair play and no harm." Article-IV establishes a Joint Committee (JC) to monitor daily water flows at the Farakka point in India and the Hardinge Bridge point in Bangladesh. Article VII says that the disputed issues need to be submitted to the JC, JRC, or the Indian and Bangladesh governments in a priority sequence respectively. Article-IX also agrees to ensure water sharing of the other common rivers and article- $\mathrm{X}$ contains options to review the treaty every five years or earlier.

However, the treaty fails to set out guidelines for flooding, drought, and river bank erosion (Bhattarai 2009; Brichieri-Colombi and Bradnock 2003). The treaty also fails to recognize the JRC as a main water management body. Article VIII focuses on the cooperation mechanisms for issues like flood management, irrigation, and hydropower, which are absent from the Indian Government practices. The Indian government fails to respect article IX that provides guidelines for resolving International River disputes based on "equity, fairness and no harm principles." The Teesta River was at the top of this list. To date, none of the disputes is resolved, including the Teesta (PTI 2014). On the other hand, the Indian government violated this article with the National River Linking Project (NRLP), which allows water transfers from the Brahmaputra to the Ganges Basin for drought prone areas in India. The JRC is not involved in the NRLP. The NRLP will create similar ecological disasters which are currently taking place in the southwest part of Bangladesh due to the Farakka diversion (Bandyopadhyay and Ghosh 2009; Bhattarai 2009; Haftendorn 2000).

Despite the existence of the treaty, the basin flow is diminishing. Though the treaty was signed in 1996, the flow has diminished from 828 cusecs in 1990 to 766 cusecs in 2001 during the dry season (Table 2). The treaty fails to restore the basin flow at the preFarakka level which creates the ecological resource failures and community livelihood challenges. These challenges extend further due to very irregular nature of seasonal flow. Chapra communities do not get a minimum water flow for agricultural production a year while they face excess water another year. Sometimes, this water flow begins earlier or later than a regular khora or borsha season which create further ecosystem failures. These failures are extremely harmful for local socioeconomic systems which are escalated by ecological vulnerabilities of flooding, drought, river bank erosion, salinity intrusion, and

Table 1 Annexure 1 of the 1996 Ganges Treaty for Sharing the Ganges Basin

\begin{tabular}{lll}
\hline Availability at Farakka & Share of India & Share of Bangladesh \\
\hline 70,000 cusecs or less & $50 \%$ & $50 \%$ \\
70,000 cusecs-75,000 cusecs & Balance of flow & 35,000 cusecs \\
75,000 cusecs or more & 40,000 cusecs & Balance of flow \\
\hline
\end{tabular}

GoB 1996. 
Table 2 Average Ganges Basin Flow at Harding Bridge Point in Bangladesh

\begin{tabular}{|c|c|c|c|c|c|c|c|c|c|c|}
\hline \multirow[t]{2}{*}{ Year } & \multirow{2}{*}{$\begin{array}{l}\text { Khora } \\
\text { Average }\end{array}$} & \multicolumn{4}{|c|}{ Khora (March-April Average) } & \multirow{2}{*}{$\begin{array}{l}\text { Bonna } \\
\text { Average }\end{array}$} & \multicolumn{4}{|c|}{ Bonna (July-August-September Average) } \\
\hline & & Max & Month & Min & Month & & Max & Month & Min & Month \\
\hline 1960 & 2326 & 2480 & Mar 07 & 2170 & Apr 30 & 39794 & 48000 & Sept 04 & 25800 & Aug 02 \\
\hline 1964 & 2320 & 2600 & Mar 01 & 2180 & Apr 15 & 39733 & 48300 & Sep 10 & 29200 & Jul 28 \\
\hline 1970 & 2360 & 2640 & Mar 11 & 2030 & Apr-24 & 32917 & 40800 & Aug 18 & 24400 & Aug 30 \\
\hline 1976 & 780 & 1130 & Mar 01 & 657 & Mar 29 & 33569 & 50000 & Aug 31 & 19100 & Jul 31 \\
\hline 1980 & 927 & 962 & Mar 02 & 874 & Mar 30 & 48350 & 57800 & Aug 22 & 37500 & Aug 02 \\
\hline 1985 & 823 & 1020 & Mar 05 & 701 & Apr 04 & 37373 & 48000 & Aug 29 & 24200 & Jul 25 \\
\hline 1990 & 828 & 1030 & Apr 29 & 698 & Mar 01 & 40444 & 51000 & Aug 21 & 23100 & Sep 09 \\
\hline 1995 & 509 & 769 & Mar 01 & 363 & Apr 26 & 35219 & 48800 & Aug 19 & 18800 & Jul 30 \\
\hline 2001 & 766 & 997 & Apr 27 & 456 & Apr 21 & 34390 & 44004 & Aug 30 & 22095 & Aug 19 \\
\hline 2006 & 828 & 1092 & Apr 07 & 418 & Apr 22 & 26271 & 35079 & Aug 31 & 21887 & Aug 15 \\
\hline 2010 & 743 & 970 & Mar 20 & 475 & Mar 31 & 25190 & 40276 & Sep 25 & 8701 & Jul 05 \\
\hline
\end{tabular}

BWDB 2012.

charland. The river flow reduction deposits siltation on the Gorai Riverbed which creates charland. This charland causes river channel by creating river bank erosion in addition to extreme flooding. These negative outcomes cause displacements and multiple social problems in local communities. These negative effects are continuous events after resuming the Farakka Barrage in 1975.

In addition to the data in Table 2, local seasonal pattern failures are evident from other data on the Ganges Basin flow in Bangladesh (BWDB 2012). On 30 March 1986, the basin flow was 1250 cusecs during the summer season, and fluctuated between 451 and 261 cusecs on 30 March 1989 and 1999 respectively. These flows further fluctuated to 1186 and 794 cusecs on 31 March 2007 and 2008 respectively. In addition to this dry seasonal ecosystem failure, the rainy season also encounters the similar problems. On 30 September 1986, the rainy seasonal flow was 16100 cusecs, which fluctuated between 28,773 and 53,595 cusecs in 1997 and 1998 respectively. This flow encountered further fluctuations to 24200, 56556 and 18270 cusecs on 30 September 1999, 2007, and 2008 respectively.

In addition to this flow fluctuation, the seasonal patterns are also fluctuating from one year to another. In 2009, for example, the dry season began in March with a flow of 602 cusecs and ended in May with the flow of 897 cusecs. Again in 1979, the dry season began in January and continued to June. In general, the dry season's length is increasing and the rainy season's flow is shrinking. For example, in 2009, the rainy season began in August and ended in September, which is shorter than a regular rainy season. This data shows that the rainy season flow did not improve after signing the treaty in 1996.

This abnormal seasonal pattern has significantly impacted local ecosystems. Rainy season failures create ecological vulnerabilities like flooding, drought, and river bank erosion, which cause major challenges for basin communities in Chapra. My focus group respondents pointed out that local croplands face continuous droughts for years, which reduce local crop species, habitats, and vegetation. Traditional occupations based on the seasonal crop patterns of kharif 2, kharif 1 , and robi are diminishing day by day. Currently, my focus group participants are losing their local ecological knowledge about borsha and khora due to these ecosystem failures.

The basin's seasonal failures dominate local water bodies at Chapra. The Gorai River fails to get a minimum of freshwater flow for its survival (Bharati and Jayakody 2011; 
Islam and Karim 2005; Sarker 2004). Local water bodies like the Chapaigachi oxbow lake, Lahineepara canal, and Chapra canal are disappearing from Chapra due to Gorai River failures. This reduced flow is increasing sedimentation and drainage congestion in the Gorai River. Drainage congestion is responsible for salinity intrusion in the Gorai River, which creates biodiversity degradation, local habitat and vegetation reduction, and local ecological challenges (Islam and Gnauck 2011; Mirza and Sarker 2004). Local fish species like eel and crop species like aman are facing extinction. Local communities in Chapra face survival challenges due to these negative outcomes. They do not get fish and cropland siltation from river flow that increases livelihood challenges. The failures of this siltation create chemical fertilizer dependency which creates crop production commodification and social inequality.

The current JRC and the 1996 Ganges Treaty fail to reduce these negative effects. The Indian government is successful in controlling the Ganges Basin. On the other hand, the survival of local communities is being challenged and many of them are being displaced. During the summer season, they face major drought and crop failures. During the rainy season, there is no regular wet season and flooding results in crop losses and livelihood vulnerabilities. The growing vulnerabilities like flooding, drought, and river bank erosion create community survival challenges at Chapra. More than ten million are now homeless among the river bank erosion affected people in south-western Bangladesh (Prothom Alo 2014).

My in-depth case respondents fail to get wild fish like carp, barb and minnow from local water bodies. Water-grown vegetables like water lily and water spinach are no longer available in local waters. Moreover, many traditional occupations like fishermen and boatmen are disappearing. These socioecological system failures are not acceptable in the context of common pool resource rights (Bardhan 1993) and ecological integrity (UN 1997) and human rights (UN 2002) perspectives. The basin countries need to find an appropriate basin management perspective to ensure the viability of ecological systems, community sustainability, and human rights protections. A water governance approach based on the democratic participation of local communities in China, Nepal, India and Bangladesh can restore Chapra community historical rights and can promote community empowerment.

\section{Water governance for community empowerment}

Ganges Basin water governance needs to recognize three major principles: multilateral approach, ecological integrity and local knowledge to promote water policy sustainability and community empowerment. This governance approach can promote a connection between the land, water, and community, which can restore the community's rights over ecological resources and environmental conservation. This approach is necessary to protect the rights of ecological citizenship (Orlove and Caton 2010) based on socioecological practices (Wagner 2013). For this purpose, a multilateral approach is a prerequisite for coordinating among communities, organizations, and institutions (Folke et al. 2005).

\section{Multilateral basin management approach}

Multilateral basin management is a prerequisite for restoring the ecological system. For this purpose, the current JRC must be restructured to include all countries in the Ganges 
Basin (Faisal 2002; Iyer 1999). Lebel et al. (2005) focus on scaling of water governance in the Mekong Region based on political process, development discourse and institutional system. This governance approach requires community inclusion for incorporating multilevel interests by developing spatial, temporal and jurisdictional scales. This multilateral institution can mediate asymmetric power and develop equitable water access for the basin countries (Bhattarai 2009; Elhance 1999) to achieve sustainable water management (Bandyopadhyay and Ghosh 2009). The new institution needs to gather base-line data related to hydrology, ecology, basin communities, water stagnation, and salinity. This integrated perspective can reduce ecological system failures and the displacement of local people (Brunee and Toope 1997). The government of India needs to recognize the root causes of these failures and displacements. The governments in Bangladesh, Nepal, and Bhutan need to raise voices over these causes and develop unity by overcoming Indian bilateral hydropolitics. The government of China can play constructive role in protecting the Ganges Basin ecological integrity and local community vital human needs according to international water laws. No state can survive with these continuous problems (Beck 1992) which cause multiple social problems (Beck 1998) and social movements (Mosse 2003:301). The failures to recognize community survival rights can raise questions against state legitimacy over the basin water resources (Mosse 2003:303).

International water laws and conventions can promote the Ganges Basin-wide water resource management (Paisley 2002). Articles IV, V (I, III), X(1), XI(2), and XXIX(4) of the Helsinki Rules (1966) focus on the principles of equitable and reasonable water sharing (ILA 1966). Article 7 of the UN Convention (1997) describes guidelines "not to cause significant" harm between the basin sharing countries. Articles 3(4.d), 3(8.b), 10(1), 12, 13(1,3), and 16 of Berlin Rules (2004) develop a reasonable and equitable water management at local, regional, national, and basin-wide levels (ILA 2004). Recognition of these guidelines can reduce Ganges Basin hydropolitics and promote basin-wide water management.

Based on the multilateral basin institution, it is important to promote a water governance approach (Mukherji and Shah 2005). The 'governance' perspective can incorporate the voices of marginalized communities in basin management. This approach requires consideration of spatial and temporal scales based on the concept of the basin as a unit of ecological embeddedness (Bulkeley 2005; Orlove and Caton 2010). The Ganges Basin spatial scale encompasses the range from the Himalaya Mountains to the Bay of Bengal. This spatial scale can promote the concept of watershed. The temporal scale can describe the historical patterns of basin hydrology including seasonal flows and agro-ecological systems. These spatial and temporal scales can promote local ecological systems and their resources like cropland siltation, fisheries, vegetation, and crop patterns.

In addition to these spatial and temporal scales, it is also important to incorporate horizontal and vertical coordination (Bulkeley 2005). Vertical coordination needs coordination among local, regional, national and basin levels by including community representatives (Manor 2004; Ostrom et al. 1999; Wagner 2010). This coordination can begin with local community resource management that can scale up to the local (e.g. Kushtia District), national (e.g. Dhaka), and the basin-wide levels. The foundations for vertical coordination are water governance at every level. For example, Chapra villagers will have their own water governance based on community members' democratic participation. This local water governance organization can elect a representative to the district level who 
represents the community's voices. The district level committee will elect a representative to represent them at the national level. The national level organization will elect a representative to represent them at the basin wide water governance institution. Representatives will also be required from the other basin countries of China, Nepal and India on the Ganges Basin. There can be more than one representative from each country depending on the institutional structures. Each member will have veto power, and no project will be implemented if a country representative raises concerns. The basin countries need to recognize this bottom-up approach if they care for local community survivals and environmental sustainability.

This bottom-up process considers the basin as an ecological unit that can harmonize relationships between water, land, and community based on knowledge of seasonal patterns (Chowdhury and Ward 2004), floodplain fisheries (Craig et al. 2004), vegetation (Crawford 2003), living with flood (Cunny 1991), and watershed (Isaak and Hubert 2001). This ecology centered water management approach can promote environmental sustainability and community empowerment in China, India, Nepal, and Bangladesh.

\section{Ecological system governance}

Ecological systems can be protected if every basin country considers the Ganges Basin as waterscapes (Baviskar 2007), watershed (Orlove and Caton 2010), and socioecological systems (Wagner 2013). The concept, watershed governance, can promote connections among forest, land, wetland, surface and ground waters, and vegetation based on the spatial and temporal scales of basin management. Current basin ecological vulnerabilities like flooding, drought, salinity, and river bank erosion can be described as major challenges for restoring previous ecological systems. Recognition of the basin ecological integrity is one major mechanism to overcome these vulnerabilities. The short term benefits of this flow can secure water and ecological services for agricultural production, food security, irrigation, and flood control. The long term benefits include habitat and biodiversity protection, which can reduce ecological vulnerabilities. These short and long term objectives in the basin water management can promote sustainable ecosystems (Baron et al. 2002).

Basin governance can recognize agro-ecological patterns of the Ganges Basin that describe linkages between croplands and seasonal patterns. My case respondents pointed out that local land use patterns depend on the rainy and summer seasons. Based on this agro-ecological system, they plant different crops at higher, intermediate, and lower croplands, which need to be recognized in basin governance. They produce triple crops like kharif-1, kharif 2, and robi at higher levels and a single crop at the lower level. This lower cropland is also where their fisheries are located. They use vita and maacha, raised platforms for crop production. These systems are ecologically sustainable based on harmony between river water, community, and croplands, and needs to be incorporated in basin governance based on spatial, temporal, and vertical coordination.

Ganges basin water governance can restore seasonal agricultural patterns. Local cropping patterns of kharif-1, kharif-2, and robi in summer, rainy, and winter seasons should be one major component of water governance. Understanding of these crop patterns can help to restore the rainy seasonal flow that is necessary for siltation and algae which promote local cropland fertility. This understanding can restore waterscapes and 
socio-ecological systems. These systems are important for protecting local crop species, habitats, and vegetation which can create space for community empowerment and environmental sustainability.

This sustainability needs to be based on spatial, temporal, vertical, and horizontal coordination. The recognition of spatial scales can include local crop patterns throughout the basin in China, Nepal, India, and Bangladesh. The temporal scale can help us to understand causal factors in the disappearance of crop species based on historical practices and their changes. Recognizing this can help to develop better water governance based on horizontal and vertical coordination. This governance approach can promote healthy relationships between the Ganges Basin and local water bodies like the Chapaigachi oxbow lake and Chapra wetland, and restore local ecological resources like siltation, water-borne wild vegetables, and fisheries. Restoration of the ecological system can improve water health, ecological health, and human health.

International water laws and conventions also set out guidelines for ecological integrity which should be the foundational guidelines for the basin water governance. Articles 20, 21, 22 and 23 of the 1997 UN Convention contain guidelines for promoting ecological health. A watershed management system can overcome the current ecological crises in the Ganges Basin. Articles 22 and 24 of Berlin Rules (2004) describe "ecological integrity" and article 24 of these rules provides guidelines for ensuring adequate water flow in a drainage basin for protecting this integrity that is important to protect aquatic environments for local habitats and vegetation based on spatial and temporal scales. Multilateral basin governance can secure these ecological systems of the Ganges Basin. For this governance purpose, local knowledge can play a major role in promoting seasonal patterns, river flow, ecological resources, land use patterns, and crop production, which is a major step for community empowerment.

\section{Local knowledge and community participation}

Domination over local knowledge with the top-down water management should stop to promote ecological systems and community sustainability (Sillitoe 2000). This domination over and exploitation of local knowledge prevents community participation in local resource management, causing gradual marginalization, displacement, and basin management failures (Nygren 1999). No water management practice can stop the growth in ecological system failures and the marginalization of local communities if the Indian government fails to recognize seasonal practices, cropland-river bond, local crop species, and habitat (Kottak 1999). Political ecology at this stage needs to come from modernism and develop a mechanism to negotiate the debate over hierarchy. For this purpose, Ganges Basin management needs to recognize water as a common good rather than a commodity. This will reduce the gap between nature and politics and can develop the political tradition with the long term objective of natural tradition, Naturpolitik (Latour 2004). To achieve this objective, it is important to promote local ecological knowledge in resource management so that local voices can be recognized in the decision making and implementation process (Berkes et al. 2000). Mosse (2001:16-19) notes that local knowledge could benefit the marginalized communities based on coordination of local knowledge with development projects.

In this context, local ecological knowledge requires epistemological recognition in local and basin-wide water management systems (Kottak 1999; Van Eijck and Roth 2007). This 
recognition can promote farming communities' beliefs, cultural practices, seasonal patterns, and festivals in these systems. It is important to concentrate on a methodological process to collect this knowledge, ranging from identification to recommendations based on community specific livelihood practices (Sillitoe 1998). In this context, basin governance needs to recognize the equal contributions of anthropologists, hydrologists, and engineers in policy formulation and implementation process. This multi-disciplinary approach can help to formulate Ganges Basin governance rules, regulations, and policies based on representation, accountability, transparency, and legitimacy (Mollinga 2008). These governance systems can promote major scope for local community participation at local, national, and basin levels (Dove 1986).

This governance system can ensure the inclusion of local communities like boatmen, fishermen, and farmers who use basin water every day in social and economic activities (Agrawal and Gibson 2001; Blaikie 2006; Leach et al. 1999). This system will be egalitarian and no hierarchy will be allowed to resolve local water concerns. The current hierarchy can be overcome with the democratic representation of grassroots communities at local, national, and basin-wide levels. This water governance is not an easy task in the current bilateral management practices and water commodification practices.

To overcome these challenges, local communities are raising their voices with social movements. These movements seek to promote bottom-up water resource management (Alier and Guha 1998; Baviskar 2003; Escobar 1996; Gadgil and Guha 1992; Ludden 2001). These movements can create scopes for dialogues between basin countries on common resources and ecological integrity, in contrast to the current bilateral and topdown practice. These dialogues are essential for capacity building and the empowerment of marginalized basin communities at Chapra. To establish real democratic practices in South Asia, more specifically in India and Bangladesh, it is important to develop water democracy (Shiva 2005) in the Ganges Basin management. This water democracy is important for promoting community sustainability by incorporating local ecological systems that can secure harmony between nature and communities. This harmony can promote the goal of green development (Baviskar 2007), which can restore the Ganges Basin waterscapes, ecological systems, and socioecological systems for sustainable development and community empowerment.

\section{Conclusion}

The flourishing and diversification of the Gorai River ecological system is the major foundation for community empowerment. Local ecological systems in Chapra describe the interconnection between land, water and community in a specific agro-ecological system. However, the current bilateral and top-down basin management is not suitable for maintaining this system. The JRC fails to protect the local ecological system and community sustainability. The Farakka Barrage domination is one example of ecosystem failures which can be overcome by establishing a multilateral water management system including China, India, Nepal, and Bangladesh.

The essence of participatory development is that it is, by its nature and its objectives, a sustainable development act. This participatory perspective incorporates negotiation and compromise between the countries on water issues, scales, and coordination. Positive coordination can help to establish a common ground for Ganges Basin water governance. 
This common ground can restore ecological systems based on multi-lateral water governance. The inclusion of local communities on seasonal cropping patterns, cropland siltation, fisheries, and vegetation can be a helpful mechanism to promote this type of governance. This inclusion is a challenging task in the current bilateral and top-down hydropolitics. Affected people are currently promoting their voices against hydropolitics to protect their ecological resources and livelihood practices. These voices can redirect basin management towards the goal of community empowerment. The Indian government needs to recognize the importance of this empowerment for ecosystem resilience and human security.

\section{Endnotes}

${ }^{\mathrm{a}} \mathrm{My}$ fieldwork was supported by the International Development Research Centre (IDRC), Canada.

bSource: http://lh5.ggpht.com/_NNjxeW9ewEc/TNI9efkNG9I/AAAAAAAAPxw/5og

R9KFFZ9Y/tmpC439_thumb1_thumb2.png?imgmax $=800$.

Received: 7 November 2014 Accepted: 10 November 2014

Published online: 01 July 2015

\section{References}

Agrawal, A. 2003. Sustainable governance of common-pool resources: context, methods, and politics. Annual Review of Anthropology 32: 243-62.

Agrawal, A, and C Gibson. 2001. Communities and the Environment: Ethnicity, Gender, and the State in Communitybased Conservations. New Brunswick: Rutgers University Press.

Ahmad, QK, and AU Ahmed. 2004. Regional Cooperation on Water and Environment in the Ganges Basin: Bangladesh Perspectives. In The Ganges Water Dispersion: Environmental Effects and Implications, ed. MM Mirza. Dordreecht: Kluwer Academic Publishers.

Alier, J, and R Guha. 1998. Varieties of Environmentalism. London: Earthscan.

Arango, L, B Casciarri, AD Geoffroy, F Ireton, and S Zug. 2010. The Status of Water: "Embeddedness" in Social Relations and Historical Background. Parish: Wamakhair Second Workshop Nanterre University. 21-23 June.

Bandyopadhyay, J. 2006. Integrated Water Systems Management in South Asia: A Framework for Research. CEP Occasional Paper 09. Calcutta: Centre for Development and Environment Policy, Indian Institute of Management.

Bandyopadhyay, J, and N Ghosh. 2009. Holistic engineering and hydro-diplomacy in the Ganges-Brahmaputra-Meghna Basin. Economic and Political Weekly XLIV(45): 50-60.

Bandyopathyay, J, and V Shiva. 1988. Political economy of ecology movements. Economic and Political Weekly 23(23): 1223-1232

Bangladesh Election Commission. 2011. Voter List of Chapra Union at Kushtia District. Dhaka: Government of Bangladesh.

Bangladesh Water Development Board. 2012. The Ganges Basin Flow Data at the Harding Bridge Station in Bangladesh. Dhaka: BWDB.

Bardhan, P. 1993. Symposium on management of local commons. Journal of Economic Perspectives 7(4): 87-92.

Baron, JS, NL Poff, PL Angermeier, CN Dahm, PH Gleick, NG Hairston Jr, RB Jackson, CA Johnston, BD Richter, and AD Steinman. 2002. Meeting ecological and societal needs for freshwater. Ecological Applications 12(5): 1247-1260.

Baviskar, A. 2003. For a Cultural Politics of Natural Resources. Economic and Political Weekly 38(48): 5051-5055.

Baviskar, A (ed.). 2007. Waterscapes: the cultural politics of natural resource. Himalaya: Permanent Black.

Beck, U. 1992. Risk society: Toward a new modernity. London: Sage.

Beck, U. 1998. In Risk, environment and modernity: towards a new modernity, ed. S Lash, B Szerszynski, and B Wynne. London: Routledge.

Berkes, F, J Colding, and C Folke. 2000. Rediscovery of traditional ecological knowledge as adaptive management. Ecological Applications 10(5): 1251-1262.

Bharati, L, and P Jayakody. 2011. Hydrological impacts of inflow and land-use changes in the Gorai River Catchment, Bangladesh. Water International 36(3): 357-369.

Bhattarai, DP. 2009. An analysis of transboundary water resources: a case study of River Brahmaputra. Journal of the Institute of Engineering 7(1): 1-7.

Biswas, AK 1999. Management of international waters: opportunities and constraints. Water Resource Development 15(4): 429-441.

Blaikie, P. 2006. Is small really beautiful? Community-based natural resource management in Malwai and Botswana. World Development 34(11): 1942-1957.

Brichieri-Colombi, S, and RW Bradnock. 2003. Geopolitics, water and development in South Asia: Cooperative development in the Ganges-Brahmaputra Delta. Royal Geographic Society with IBG 169(1): 43-64.

Brunee, J, and SJ Toope. 1997. Environmental security and freshwater resources: Ecosystem regime building. The American Journal of International Law 91(1): 26-59.

Bulkeley, H. 2005. Reconfiguring environmental governance: Towards a politics of scales and networks. Political Geography 24: 875-902.

Castro, JE. 2007. Water governance in the twentieth-first century. Campinas X(2): 97-118. 
Chowdhury, MR, and N Ward. 2004. Hydro-meteorological variability in the Greater Ganges-Brahmaputra-Meghna Basins. International Journal of Climatology 24: 1495-1508.

Craig, JF, AS Halls, JJ Barr, and CW Bean. 2004. The Bangladesh floodplain fisheries. Fisheries Research 66: 271-286.

Crawford, RC. 2003. Riparian Vegetation Classification of the Columbia Basin, Washington. Natural Heritage Program Report 2003-03. Olympia, WA: Washington Dept. Natural Resources.

Crow, B, and N Singh. 2000. Impediments and innovations in international rivers: The Waters of South Asia. World Development 28(11): 1907-1925.

Cunny, FC. 1991. Living with floods: Alternatives for Riverine Flood Mitigation. Land Use Policy 8(4): 331-334.

D'Souza, R. 2006. Water in British India: The Making of a 'Colonial Hydrology.'. History Compass 4(4): 621-628.

Dove, MR. 1986. Peasant versus government perception and use of the environment: A Case-Study of Banjarese Ecology and River Basin Development in South Kalimantan. Journal of Southeast Asian Studies 17(1): 113-136.

Elhance, AP. 1999. Hydro-politics in the Third World: Conflict and Cooperation in International River Basins. Washington: United States Institutes of Peace Press.

Escobar, A. 1996. Construction nature: Elements for a Post-structuralist Political Ecology. Futures 28(4): 325-343.

Faisal, IM. 2002. Managing common waters in the Ganges-Brahmaputra-Meghna Region. SAIS Review 22(2): 309-327.

Folke, C, T Hahn, P Olsson, and Jon Norberg. 2005. Adaptive governance of social-ecological systems. Annual Review of Environment and Resources 30: 441-73.

Gadgil, M, and R Guha. 1992. This fissured land: an ecological history of India. Berkeley: University of California Press.

Government of Bangladesh (GoB). 1996. Treaty Between the Government of the People's Republic of Bangladesh and the Government of the Republic of India on Sharing of the Ganga/Ganges Waters at Farakka.. Available at http://www.jrcb.gov.bd/attachment/Gganges_Water_Sharing_treaty,1996.pdf. Accessed January 12, 2014.

Gupta, AD, MS Babel, X Albert, and O Mark. 2005. Water sector of Bangladesh in the Context of Integrated Water Resources Management: A review. Water Resources Development 21(2): 385-398.

Haftendorn, H. 2000. Water and International Conflict. Third World Quarterly 21(1): 51-68.

Hartmann, B, and JK Boyce. 1983. A Quiet Violence. London: Zed Press.

Hastrup, K. 2013. Water and the configuration of social worlds: An anthropological perspective. Journal of Water Resource and Protection 5: 59-66.

Hill, D. 2006. The Politics of Water in South Asia. Transforming Cultures eJournal 1(2): 135-158.

Hossain, I. 1981. Bangladesh-India relations: Issues and problems. Asian Survey 21(11): 115-1128.

Hossain, I. 1998. Bangladesh-India relations: The Ganges water-sharing treaty and beyond. Asian Affairs 25(3): 131-150.

Hossen, MA. 2012. Bilateral hydro-hegemony in the Ganges-Brahmaputra Basin. Oriental Geographer 3(53): 1-18.

Hukka, JJ, JE Castro, and PE Pietila. 2010. Water, policy and governance. Environment and History 16: 235-251.

International Law Association. 1966. The Helsinki Rules on the Uses of the Waters of International Rivers.. Available at: http//www.unece.org/env/water/meetings/legal_board/2010/annexes_groundwater_paper/Annex_II_Helsinki_Rules_ILA.pdf. Accessed July 12, 2013.

International Law Association. 2004. Berlin Conference (2004) Water Resources Law. Available at: http://www. internationalwaterlaw.org/documents/intldocs/ILA_Berlin_Rules-2004.pdf. Accessed July 10, 2013.

Isaak, DJ, and WA Hubert. 2001. Production of stream habitat gradients by Montane Watersheds: Hypothesis tests based on spatially explicit path analyses. Canadian Journal of Fisheries and Aquatic Sciences 58: 1089-1103.

Islam, SN, and A Gnauck. 2011. Water Shortage in the Gorai River Basin and Damage of Mangrove Wetland Ecosystems in Sundarbans, Bangladesh, Paper Presented at the 3rd International Conference on Water \& Food Management (ICWFM-2011), Dhaka, January 8-10.

Islam, GMT, and MR Karim. 2005. Predicting downstream hydraulic geometry of the Gorai River. Journal of Civil Engineering (IEB) 33(2): 55-63.

Iyer, RR. 1999. Conflict-resolution: Three River treaties. Economic and Political Weekly 34(24): 1509-1518.

Khalid, I. 2010. Bangladesh water concern. South Asian Studies 25(1): 73-87.

Khan, TR. 1996. Managing and sharing of the Ganges. Natural Resources Journal 36: 455-479.

Kottak, CP. 1999. The new ecological anthropology. American Anthropologist 101(1): 23-35.

Latour, B. 2004. Politics of nature: How to bring the sciences into Democracy, translated by C. Porter. Cambridge \& London: Harvard University Press.

Leach, M, R Mearns, and I Scoones. 1999. Environmental entitlements: Dynamics and Institutes in Community-Based Natural Resource Management. World Development 27(2): 225-247.

Lebel, L, P Garden, and M Imamura. 2005. The politics of scale, position, and place in the Governance of Water Resources in the Mekong. Ecology and Society 10(2): 18.

Ludden, D. 2001. Subalterns and Others in the Agrarian History of South Asia. In Agrarian studies: Synthetic work at the cutting edge, ed. JC Scott and N Bhatt. Yale: The Yale ISPS Series.

Manor, J. 2004. Democratization with Inclusion: Political Reforms and People's Empowerment at the Grassroots. Journal of Human Development and Capabilities 5(1): 5-29.

McGregor, J. 2000. The Internationalization of Disputes over Waters: The Case of Bangladesh and India, Paper presented at the Australasian Political Studies Association Conference, Canberra, October 3-6.

Ministry of Water Resources (MoWR). N. d. Statute of the Indo-Bangla Joint Rivers Commission. Available at http://www. jrcb.gov.bd/statute.html. Accessed January 9, 2014.

Mirumachi, N, and JA Allan. 2007. Revisiting transboundary water governance: Power, conflict cooperation and the political economy, Proceedings from CAIWA International Conference on Adaptive and Integrated Water Management: Coping with Scarcity. Basel, Switzerland, 12-15 November 2007.

Mirza, MM (ed.). 2004. The Ganges Water Dispersion: Environmental Effects and Implications. Dordreecht: Kluwer Academic Publishers.

Mirza, MQ, and MH Sarker. 2004. Effects on water salinity in Bangladesh. In The Ganges water dispersion: Environmental effects and implications, ed. MM Mirza. Netherlands: Kluwer Academic Publishers.

Mollinga, PP. 2008. Water, politics, and development: framing a political sociology of water resources management. Water Alternatives 1(1): 7-23. 
Mosse, D. 2001. People's knowledge', participation and patronage: Operations and representations in rural development. In Participation: The new tyranny? ed. B Cooke and U Kothari. London and New York: Zed Books.

Mosse, D. 2003. The rule of water: statecraft, ecology, and collective action in South India. New Delhi: Oxford University Press. Mukherji, A, and T Shah. 2005. Groundwater Socio-ecology and Governance: A Review of Institutions and Policies in Selected Countries. Hydrogeology Journal 13: 328-345.

Nakayama, M. 1997. Success and failures of International Organizations in Dealing with International Waters. Water Resources Development 13(3): 367-382.

Nilsson, C, CA Reidy, M Dynesius, and C Revenga. 2005. Fragmentation and flow regulation of the World's Large River Systems. Science 308: 405.

Nishat, A, and IM Faisal. 2000. An assessment of the mechanism for water Negotiation in the Ganges-Brahmaputra-Meghna System. International Negotiation 5: 289-310.

Nygren, A. 1999. Local knowledge in the Environment-Development Discourse: From dichotomies to situated knowledge. Critique of Anthropology 19(3): 267-288.

Orlove, B, and SC Caton. 2010. Water sustainability: Anthropological es and prospects. The Annual Review of Anthropology 39: $401-15$

Ostrom, E, J Burger, CB Field, RB Norgaard, and D Policansky. 1999. Revisiting the commons: Local lessons, global challenges. Science 284(5412): 278-282.

Paisley, R. 2002. Adversaries into partners: International water law and the equitable sharing of downstream benefits. Melbourne Journal of International Law 3(2): 280-300.

Parua, PK. 2010. The Ganga: Water Use in the Indian Subcontinent: Necessity of Regional Cooperation. London \& New York: Springer Dordrecht Heidelberg.

Peterson, G. 2000. The human actor in ecological-economics models, political ecology and ecological resilience: An Integration of Human and Ecological Dynamics. Ecological Economics 35: 323-336.

Polanyi, K. 1944. The great transformation. New York: Farrar and Rinehart.

Prothom Alo. 2014. No Government Preparation is Available: Two Crore People are Victims of River Bank Erosion for the Last 36 Years and One Thousand Losses Every Year. http://prothom-aloblog.com/posts/16/46251/, accessed June 21.

PTI. 2014. Teesta Treaty Difficult Issue: PM Manmohan Singh Tells Bangladesh's Sheikh Hasina. http://www.dnaindia.com/ india/report-teesta-treaty-difficult-issue-manmohan-singh-tells-sheikh-hasina-1966754, accessed April 5, 2014.

Rahaman, MM. 2009. Principles of transboundary water resources management and ganges treaties: An analysis. International Journal of Water Resources Development 25(1): 159-173.

Sarker, MH. 2004. Impact of upstream human interventions on the morphology of the Ganges-Gorai System. In The Ganges water dispersion: Environmental effects and implications, ed. MM Mirza. Netherlands: Kluwer Academic Publishers.

Shiva, V. 2005. Earth democracy: Justice, sustainability, and peace. Massachusetts: South End Press.

Sillitoe, P. 1998. What, know natives? Local knowledge in development. Social Anthropology Today 6(2): 203-220.

Sillitoe, P (ed.). 2000. Indigenous knowledge development in Bangladesh: Present and future. Dhaka: The University Press Limited.

Swain, A. 1996. Displacing the conflict: Environmental destruction in Bangladesh and Ethnic Conflict in India. Journal of Peace Research 33(2): 189-204.

United Nations. 1997. Convention on the Law of the Non-navigational Uses of International Watercourses.. Available at: http://www.un.org/law/cod/watere.htm. Accessed December 12, 2013.

United Nations. 2002. The right to water and sanitation: Articles 11 and 12 of the International Covenant on Economic Social and Cultural Rights. Geneva: UN

Van Eijck, M, and W Roth. 2007. Keeping the local: Recalibrating the Status of Science and Traditional Ecological Knowledge (TEK) in Education. Science Education 91(6): 926-947.

Wagner, J. 2010. Water Governance Today. Anthropology News 51(1): 5-9.

Wagner, J (ed.). 2013. The social life of water. New York: Berghahn.

Whiteman, G, and WH Cooper. 2000. Ecological embeddedness. Academy of Management Journal 43(6): $1265-82$.

\section{Submit your manuscript to a SpringerOpen ${ }^{\circ}$ journal and benefit from:}

- Convenient online submission

- Rigorous peer review

- Immediate publication on acceptance

- Open access: articles freely available online

- High visibility within the field

- Retaining the copyright to your article

Submit your next manuscript at $>$ springeropen.com 